\title{
Dinamika Tutupan Lahan Kawasan Hutan Lindung Air Telang Menggunakan Teknik Overlay Multitemporal
}

\author{
Syaiful Eddy ${ }^{1 *}$, Dian Mutiara ${ }^{1}$ \\ *e-mail: syaifuleddy@ gmail.com \\ ${ }^{1}$ Jurusan Biologi, Fakultas Matematika dan Ilmu Pengetahuan Alam, \\ Universitas PGRI Palembang
}

\begin{abstract}
Identification of various types of land cover in the Air Telang Protected Forest has been carried out during the period 1989-2013. The method used in identifying the dynamics of land cover in this area is the survey method of land cover changes based on time series remote sensing data in 1989, 2001 and 2013. Analysis of data in this study was in the form of analysis of land cover changes in Air Telang Protected Forest using GIS with a two-period overlay of time series technique namely the period 19892001 and 2001-2013. The results showed that there were around $55.11 \%(6,978.00 \mathrm{ha})$ of primary forest that still survived during period 1 (1989-2001) and around 44.8\% (5,671.53 ha) in period 2 (2001-2013). The area of primary forest increases because of the succession of several types of land cover, such as secondary forests, coconut plantations, swamp shrubs, ponds and water bodies into primary forests. The reduction in primary forest area is caused by the conversion of forests by communities into coconut plantations, oil palm plantations and ponds, and illegal logging. The Air Telang Protected Forest area needs to be restored in an effort to maintain its function as a protected forest.
\end{abstract}

Keywords: overlay of time series, Air Telang Protected Forest, dynamics of land cover

\begin{abstract}
ABSTRAK
Identifikasi berbagai tipe tutupan lahan di Hutan Lindung Air Telang (HLAT) telah dilakukan selama periode tahun 1989-2013. Metode yang digunakan dalam mengidentifikasi dinamika tutupan lahan di wilayah ini adalah metode survey terhadap perubahan tutupan lahan berdasarkan data penginderaan jauh multitemporal tahun 1989, 2001 dan 2013. Analisis data dalam penelitian ini berupa analisis perubahan tutupan lahan di HLAT menggunakan GIS dengan teknik overlay multitemporal dua periode yaitu periode tahun 1989-2001 dan 2001-2013. Hasil penelitian menunjukkan bahwa ada sekitar 55,11\% (6.978,00 ha) hutan primer yang masih bertahan selama periode 1 (1989-2001) dan sekitar 44,8\% (5.671,53 ha) pada periode 2 (2001-2013). Luas hutan primer bertambah karena adanya suksesi beberapa tipe tutupan lahan, seperti hutan sekunder, kebun kelapa, belukar rawa, tambak dan badan air menjadi hutan primer. Sedangkan berkurangnya luas hutan primer disebabkan karena adanya konversi hutan oleh masyarakat menjadi perkebunan kelapa, perkebunan kelapa sawit dan tambak, serta penebangan hutan secara liar. Kawasan HLAT perlu direstorasi dalam upaya untuk mempertahankan fungsinya sebagai hutan lindung.
\end{abstract}

Kata Kunci: overlay multitemporal, Hutan Lindung Air Telang, dinamika tutupan lahan 


\section{PENDAHULUAN}

Hutan mangrove memiliki ekosistem yang unik dan merupakan sumber daya alam yang potensial di wilayah pesisir (Wibowo dan Handayani, 2006). Namun, ekosistem ini bersifat labil karena mudah rusak akibat gangguan dan sulit untuk dipulihkan kembali (Anwar dan Gunawan, 2006).

Menurut Giesen et al. (2007), hampir 60\% hutan mangrove di Asia Tenggara berada di Indonesia, sementara sisanya berada di Malaysia (11,7\%), Myanmar $(8,8 \%)$, Papua New Guinea $(8,7 \%)$, Thailand $(5,0 \%)$ dan beberapa negara lainnya. Walaupun Indonesia memiliki hutan mangrove terluas di Asia Tenggara, namun kondisi hutan mangrove di Indonesia cukup mengkhawatirkan karena terdegradasi. Penyebab terbesar degradasi hutan mangrove di Indonesia adalah akibat aktivitas manusia (Eddy et al., 2015).

Hutan Lindung Air Telang (HLAT) adalah salah satu hutan lindung yang ada di Provinsi Sumatera Selatan yang terletak di Kabupaten Banyuasin yang saat ini telah mengalami degradasi dan konversi. HLAT memiliki luas sekitar 12.660,87 ha, namun lebih dari setengah bagian hutan lindung ini telah mengalami degradasi dan konversi menjadi perkebunan kelapa dan kelapa sawit, tambak ikan dan udang, pertanian serta pemukiman (Eddy et al., 2017). Wilayah Tanjung Api-Api yang berdekatan dengan hutan lindung ini juga akan dijadikan Kawasan Ekonomi Khusus (KEK). Berbagai aktivitas baik oleh masyarakat, pemerintah maupun perusahaan di Kawasan HLAT dan sekitarnya akan berdampak terhadap kelangsungan kawasan ini, karena disamping dapat memicuh percepatan degradasi juga rawan menimbulkan konflik pemilikan lahan.

Kawasan HLAT ini sangat menarik untuk dikaji karena merupakan kawasan hutan lindung yang seharusnya dikonservasi, namun sudah banyak terdegradasi akibat berbagai kegiatan antropogenik sehingga terjadi dinamika perubahan tutupan lahan secara periodik. Kajian melalui penginderaan jauh menggunakan teknik overlay multitemporal akan membantu dalam mengidentifikasi besarnya perubahan tutupan lahan dari satu jenis ke jenis yang lain dalam suatu wilayah, sehingga akan memberikan informasi secara akurat besarnya luasan hutan yang terdegradasi atau terkonversi serta luasan perubahannya secara multitemporal.

Pengolahan, analisis dan interpretasi data penginderaan jauh dapat memberikan informasi tentang sebaran, luasan dan perubahan tutupan hutan mangrove serta perubahan lingkungan yang terjadi, seperti pergeseran garis pantai (Suwargana, 2008). Teknik overlay multitemporal dapat digunakan untuk mendapatkan data tingkat perubahan kerapatan vegetasi dan luasannya (Irawan dan Sirait, 2017; Romiyanto et al., 2015). Selain itu, teknik ini juga dapat digunakan untuk mengetahui perubahan tutupan lahan lainnya seperti tutupan lahan Daerah Aliran Sungai (DAS) dan pergeseran garis pantai (Kasim, 2012; Utomowati, 2017).

Penelitian ini bertujuan untuk mengidentifikasi besarnya perubahan tutupan lahan dari satu jenis tutupan lahan ke jenis yang lain dengan teknik overlay multitemporal yaitu pada periode 1989-2001 dan 2001-2013.

\section{BAHAN DAN METODE}

\section{Lokasi Penelitian}

Penelitian ini dilaksanakan di Kawasan HLAT yang merupakan kawasan hutan mangrove yang terletak di Kabupaten Banyuasin Provinsi Sumatera 
Selatan yang luasnya sekitar $12.660,87$ ha (Gambar 1). Kawasan ini merupakan hamparan areal dengan batas-batas wilayah sebagai berikut: (1) sebelah utara berbatasan dengan Selat Bangka dan Sungai Banyuasin, (2) sebelah timur berbatasan dengan Kecamatan Muara Telang dan Kecamatan Banyuasin II, (3) sebelah selatan berbatasan dengan Kecamatan Muara Telang, dan (4) sebelah barat berbatasan dengan Sungai Banyuasin (Dinas Kehutanan dan Perkebunan Kabupaten Banyuasin, 2010).

\section{Metode Penelitian}

Penelitian ini menggunakan metode survey untuk memperoleh data berupa fakta yang sesungguhnya. Data-data dikumpulkan melalui observasi terhadap perubahan tutupan lahan di HLAT berdasarkan data penginderaan jauh secara multitemporal, yaitu tahun 1989, 2001 dan 2013. Selanjutnya dilakukan groundcheck terhadap kondisi yang sesungguhnya di lapangan. Analisis data dalam penelitian ini berupa analisis perubahan tutupan lahan di HLAT menggunakan Geographic Information System (GIS) dengan teknik overlay (tumpang tindih) multitemporal, yaitu antara tahun 1989-2001 dan 2001-2013. Metode klasifikasi yang digunakan adalah metode klasifikasi terbimbing yaitu mengelompokkan citra ke dalam beberapa kelas penutupan lahan dengan mengacu pada peta dasar, dan kemudian melakukan verifikasi lapangan untuk masing-masing penutupan lahan tersebut.

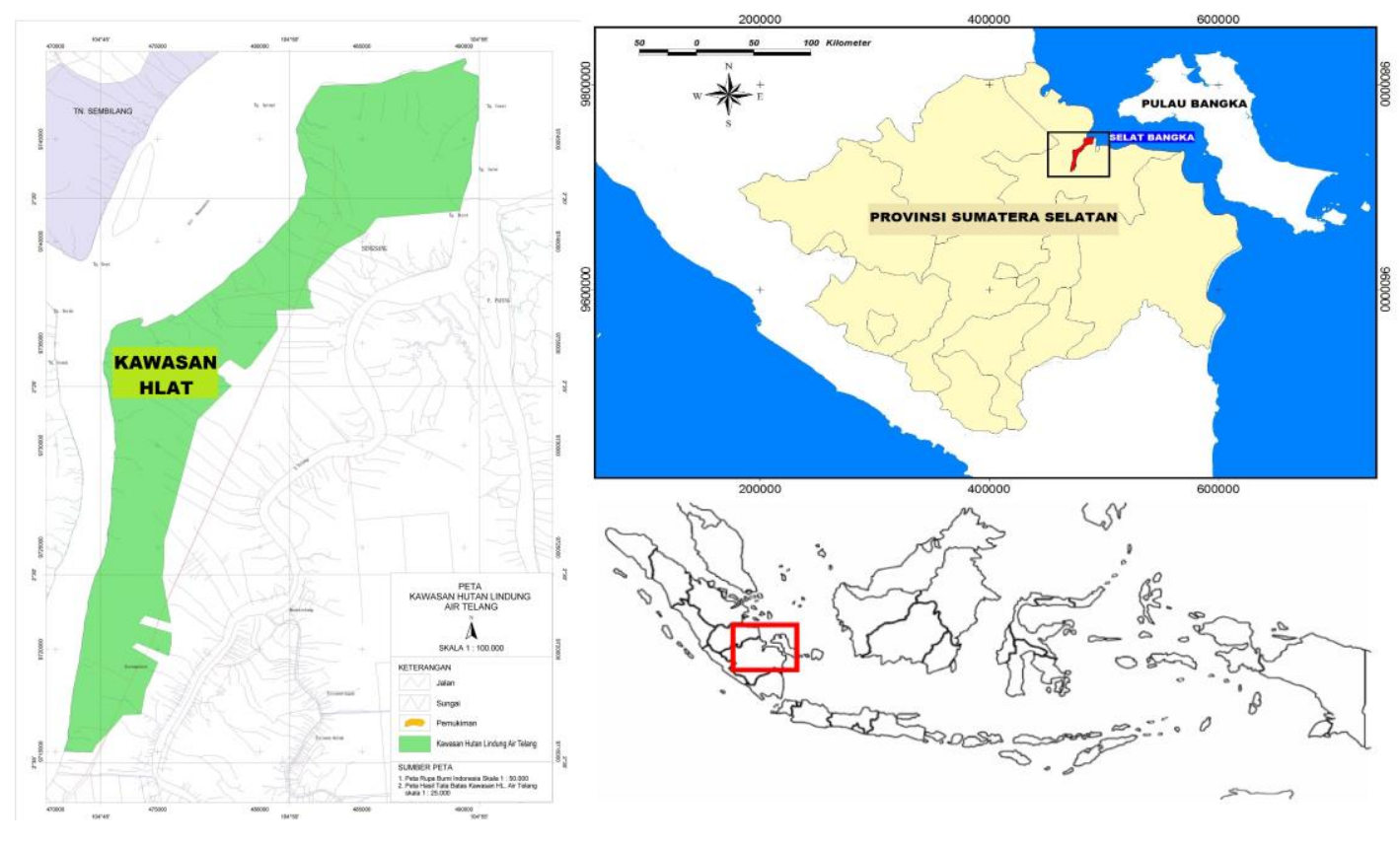

Gambar 1. Peta lokasi Kawasan Hutan Lindung Air Telang (HLAT) (Sumber: Eddy et al. (2017); Dinas Kehutanan Provinsi Sumatera Selatan (2014) dengan modifikasi).

\section{Analisis Perubahan Tutupan Lahan}

Analisis perubahan tutupan lahan dilakukan untuk membuat klasifikasi tutupan lahan serta analisis perubahan tutupan lahan di Kawasan HLAT. Analisis tutupan lahan dilakukan dengan GIS menggunakan program ArcView 3.3. Adapun klasifikasi tutupan lahan dibagi 
berdasarkan tipe penggunaan lahan dan kerapatan tajuk. Tipe penggunaan lahan dapat diklasifikasikan menjadi beberapa tipe, yaitu: (1) hutan primer, (2) hutan sekunder, (3) perkebunan kelapa, (4) perkebunan kelapa sawit, (5) belukar rawa, (6) tambak, (7) pelabuhan, dan (8) badan air.

Spesifikasi data Citra Landsat yang digunakan untuk tahun 1989, 2001 dan 2013 masing-masing adalah Landsat 5 TM, Landsat 7 ETM+ dan Landsat 8 ETM+. Analisis data multitemporal mengikuti empat tahapan yaitu preprocessing, processing, klasifikasi citra dan survey lapangan (Eddy et al., 2017). Analisis perubahan tutupan lahan dilakukan dengan teknik overlay terhadap dua citra yang telah diolah (multitemporal) yaitu periode 1989-2001 dan 2001-2013, sehingga dapat diketahui perubahan luasan obyek yang diamati. Melalui cara ini dapat diketahui luas perubahan penutupan lahan yang terjadi pada ekosistem hutan mangrove.

$\quad$ Data-data yang berhasil
dikumpulkan dianalisis dengan
menggunakan software pengolah data
numerik untuk mendapatkan luas
perubahan tutupan lahan untuk setiap
masing-masing kelas.

\section{HASIL DAN PEMBAHASAN}

Area studi dalam penelitian ini merupakan area yang sudah dipengaruhi oleh faktor-faktor antropogenik, seperti pembangunan pemukiman, perkebunan, pertanian, tambak, pelabuhan dan pemanfaatan kayu oleh masyarakat, yang menyebabkan penurunan tutupan hutan mangrove terutama hutan mangrove primer. Beberapa penyebab degradasi di area studi terlihat pada Gambar 4 yang berupa konversi lahan menjadi perkebunan kelapa sawit, perkebunan kelapa, tambak dan pelabuhan.
Peta perubahan tutupan lahan periode tahun 1989-2001 dan tahun 20012013 di HLAT dapat dilihat pada Gambar 2 dan 3. Hutan primer (Gambar 4A) tetap bisa dipertahankan luasnya sebesar $6.978,00$ ha $(55,11 \%)$ pada periode tahun 1989-2001 (periode 1), sedangkan pada periode tahun 2001-2013 (periode 2) masih bisa dipertahankan sebesar $5.671,53$ ha $(44,8 \%)$ (Tabel 1). Hal ini menunjukkan bahwa ada pengurangan luas hutan primer yang masih bisa dipertahankan sekitar 1.306,47 ha di antara dua periode ini.

Luas hutan primer pada periode 1 bertambah karena adanya perubahan dari hutan sekunder (Gambar 4B), kebun kelapa (Gambar 4F), belukar rawa dan badan air menjadi hutan primer dengan penambahan luas berturut-turut adalah sebesar 170,18; 658,47; 127,29 dan 197,55 ha, sehingga luas hutan primer pada tahun 2001 tercatat sebesar 8.131,49 ha. Sedangkan pada periode 2, luas hutan primer bertambah karena adanya perubahan hutan sekunder, kebun kelapa, tambak (Gambar 4D) dan badan air menjadi hutan primer dengan penambahan luas berturut-turut adalah sebesar 595,73; 4,53; 130,40 dan 183,09 ha, sehingga luasnya pada tahun 2013 sebesar 6.585,28 ha.

Pengurangan luas hutan primer terbesar pada periode 1 adalah akibat berubah menjadi hutan sekunder yaitu sebesar 1.969,46 ha, sedangkan pada periode 2 terjadi perubahan sebesar 775,15 ha. Terbentuknya hutan sekunder ini disebabkan karena aktivitas penebangan liar oleh masyarakat disamping akibat pembukaan hutan primer untuk perkebunan dan tambak. Hutan yang telah ditebangi dan diambil manfaatnya oleh masyarakat kemudian ditinggalkan, sehingga hutan mengalami proses suksesi untuk tumbuh menjadi hutan sekunder. 


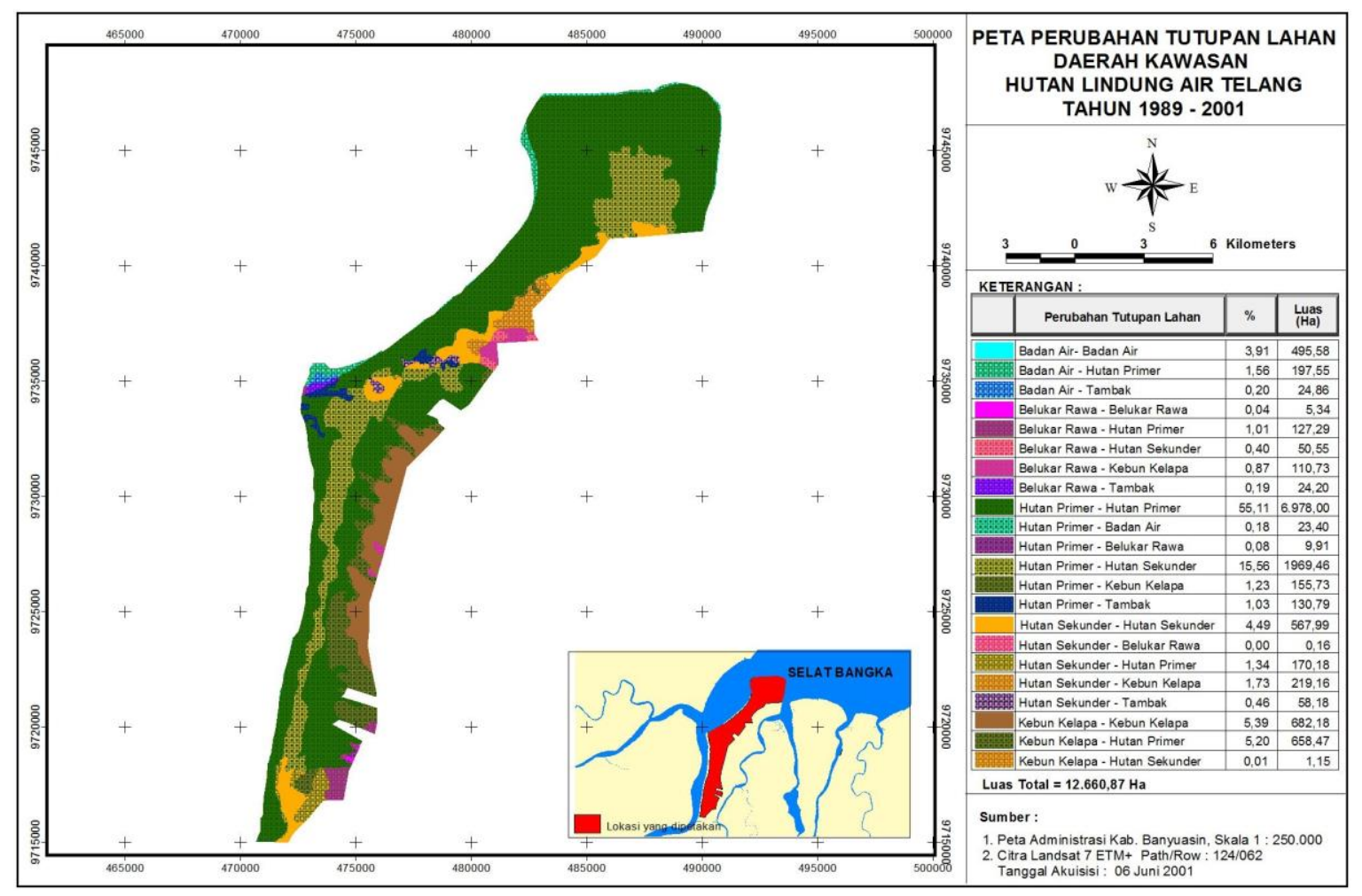

Gambar 2. Peta perubahan tutupan lahan di Kawasan HLAT pada periode tahun 19892001.

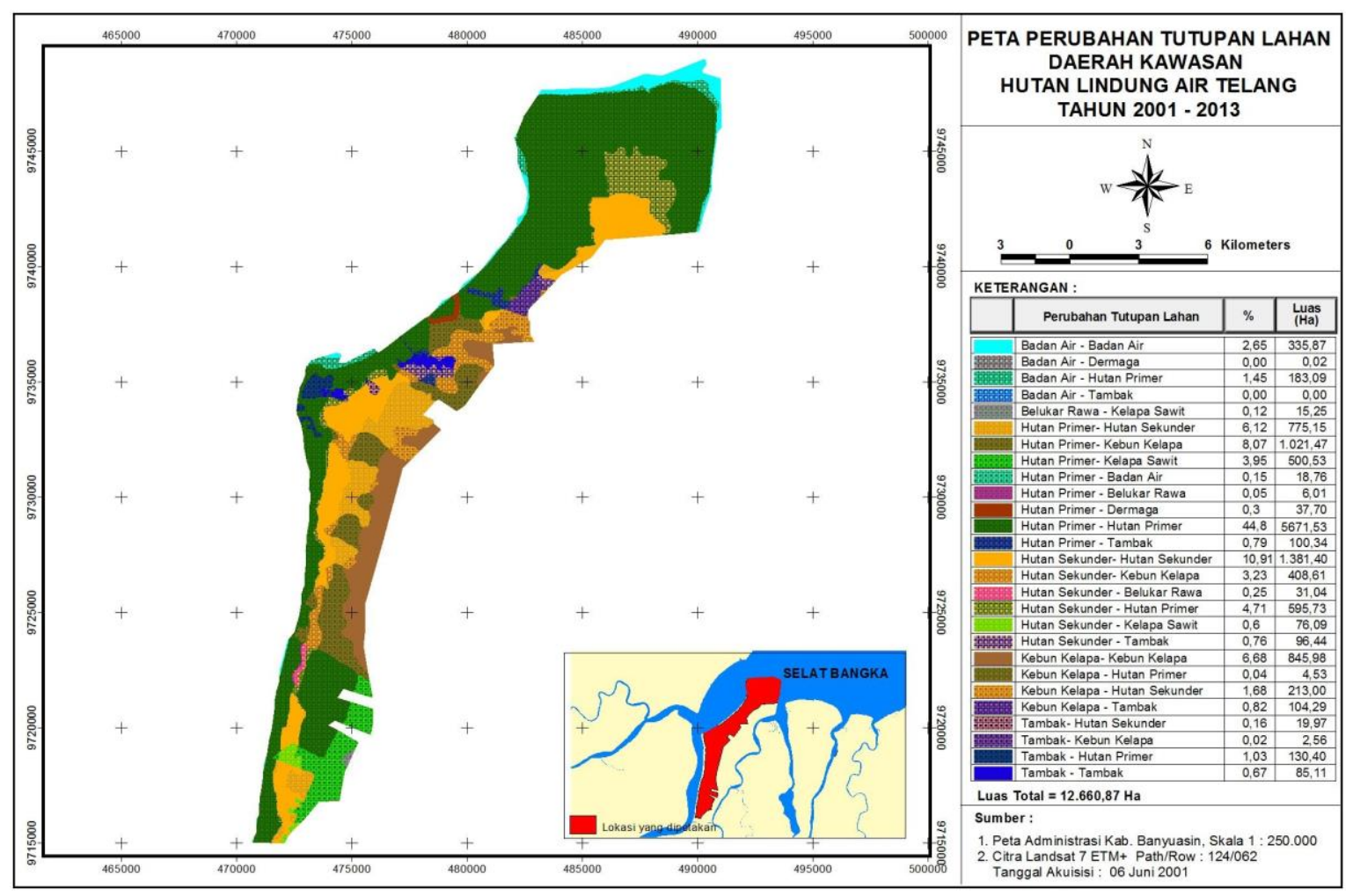

Gambar 3. Peta perubahan tutupan lahan di Kawasan HLAT pada periode tahun 20012013. 
Hutan sekunder juga terbentuk karena adanya suksesi dari belukar rawa menjadi hutan sekunder pada periode 1 yaitu sebesar 50,55 ha. Hal ini dapat terjadi karena belukar rawa menyediakan iklim mikro yang baik untuk pertumbuhan biji-biji tumbuhan khususnya tumbuhan mangrove yang kemudian mengubahnya menjadi hutan sekunder dalam rentang waktu sekitar 12 tahun (1 periode). Pada periode 2 terjadi perubahan kebun kelapa menjadi hutan sekunder yaitu sebesar 213,00 ha. Hal ini terjadi karena kebun kelapa yang kurang produktif dibiarkan begitu saja oleh masyarakat sehingga mengubahnya menjadi hutan sekunder dalam rentang waktu lebih kurang 12 tahun kemudian.

Tabel 1. Luas perubahan tutupan lahan berdasarkan tipe-tipe tutupan lahan yang ada di HLAT.

\begin{tabular}{|c|c|c|c|c|c|c|c|c|c|}
\hline \multirow[b]{2}{*}{ Tipe Tutupan Lahan } & \multicolumn{9}{|c|}{ Luas Perubahan Tutupan Lahan (ha) } \\
\hline & $\begin{array}{l}\text { Hutan } \\
\text { Primer }\end{array}$ & $\begin{array}{c}\text { Hutan } \\
\text { Sekunder }\end{array}$ & $\begin{array}{l}\text { Kebun } \\
\text { Kelapa }\end{array}$ & $\begin{array}{c}\text { Kebun } \\
\text { Kelapa } \\
\text { Sawit }\end{array}$ & $\begin{array}{c}\text { Belukar } \\
\text { Rawa }\end{array}$ & Tambak & Pelabuhan & $\begin{array}{c}\text { Badan } \\
\text { Air }\end{array}$ & Total \\
\hline \multicolumn{10}{|l|}{ Tahun 1989-2001 } \\
\hline Hutan Primer & 6978,00 & 1969,46 & 155,73 & 0,00 & 9,91 & 130,79 & 0,00 & 23,40 & 9267,29 \\
\hline Hutan Sekunder & 170,18 & 568,15 & 219,16 & 0,00 & 0,00 & 58,18 & 0,00 & 0,00 & 1015,67 \\
\hline Kebun Kelapa & 658,47 & 1,15 & 682,18 & 0,00 & 0,00 & 0,00 & 0,00 & 0,00 & 1341,80 \\
\hline Kebun Kelapa Sawit & 0,00 & 0,00 & 0,00 & 0,00 & 0,00 & 0,00 & 0,00 & 0,00 & 0,00 \\
\hline Belukar Rawa & 127,29 & 50,55 & 110,73 & 0,00 & 5,34 & 24,20 & 0,00 & 0,00 & 318,11 \\
\hline Tambak & 0,00 & 0,00 & 0,00 & 0,00 & 0,00 & 0,00 & 0,00 & 0,00 & 0,00 \\
\hline Pelabuhan & 0,00 & 0,00 & 0,00 & 0,00 & 0,00 & 0,00 & 0,00 & 0,00 & 0,00 \\
\hline Badan Air & 197,55 & 0,00 & 0,00 & 0,00 & 0,00 & 24,86 & 0,00 & 495,59 & 718,00 \\
\hline Total & 8131,49 & 2589,31 & 1167,80 & 0,00 & 15,25 & 238,03 & 0,00 & 518,99 & 12660,87 \\
\hline \multicolumn{10}{|l|}{ Tahun 2001-2013 } \\
\hline Hutan Primer & 5671,53 & 775,15 & 1021,47 & 500,53 & 6,01 & 100,34 & 37,70 & 18,76 & 8131,49 \\
\hline Hutan Sekunder & 595,73 & 1381,40 & 408,61 & 76,09 & 31,04 & 96,44 & 0,00 & 0,00 & 2589,31 \\
\hline Kebun Kelapa & 4,53 & 213,00 & 845,98 & 0,00 & 0,00 & 104,29 & 0,00 & 0,00 & 1167,80 \\
\hline Kebun Kelapa Sawit & 0,00 & 0,00 & 0,00 & 0,00 & 0,00 & 0,00 & 0,00 & 0,00 & 0,00 \\
\hline Belukar Rawa & 0,00 & 0,00 & 0,00 & 15,25 & 0,00 & 0,00 & 0,00 & 0,00 & 15,25 \\
\hline Tambak & 130,40 & 19,97 & 2,56 & 0,00 & 0,00 & 85,11 & 0,00 & 0,00 & 238,04 \\
\hline Pelabuhan & 0,00 & 0,00 & 0,00 & 0,00 & 0,00 & 0,00 & 0,00 & 0,00 & 0,00 \\
\hline Badan Air & 183,09 & 0,00 & 0,00 & 0,00 & 0,00 & 0,00 & 0,02 & 335,87 & 518,98 \\
\hline Total & 6585,28 & 2389,52 & 2278,62 & 591,87 & 37,05 & 386,18 & 37,72 & 354,63 & 12660,87 \\
\hline
\end{tabular}

Lahan perkebunan kelapa teridentifikasi selama periode 1 dan 2, dimana terjadi peningkatan pada periode 2. Konversi hutan primer dan sekunder oleh masyarakat menjadi kebun kelapa pada periode 1 adalah masing-masing sebesar 155,73 dan 219,16 ha, sedangkan pada periode 2 masing-masing sebesar $1.021,47$ dan 408,61 ha. Perkebunan kelapa merupakan usaha yang cocok dilakukan di kawasan HLAT yang berada di pesisir. Masyarakat yang mengusahakan perkebunan ini adalah masyarakat Bugis. Perkebunan ini semakin luas pada periode 2 dan banyak mengkonversi hutan primer.

Perkebunan kelapa sawit (Gambar 4C) baru teridentifikasi pada periode 2 di bagian selatan HLAT dengan mengkonversi hutan primer dan sekunder masing-masing sebesar 500,53 dan 76,09 ha. Demikian juga halnya pelabuhan (Gambar 4E) yang dibangun setelah tahun 2001, baru teridentifikasi pada periode 2. Tambak teridentifikasi mulai periode 1 dan makin meningkat luasnya pada periode 2, dimana kegiatan ini telah mengkonversi hutan primer pada periode 1 dan 2 berturut-turut sebesar 130,79 dan 100,34 ha. Menurut Eddy et al. (2017), perkebunan kelapa, perkebunan kelapa sawit dan tambak di wilayah HLAT memiliki kecenderungan meningkat jumlahnya.

Penambahan luas hutan primer pada periode 1 karena adanya perubahan hutan sekunder, kebun kelapa, belukar rawa dan badan air menjadi hutan primer 
dengan luas masing-masing adalah 170,18; 658,47; 127,29 dan 197,55 ha. Pada periode 2 juga terjadi penambahan luas hutan primer diantaranya diakibatkan oleh perubahan hutan sekunder, tambak dan badan air menjadi hutan primer dengan luas masing-masing adalah 595,73; 130,40 dan 183,09 ha.

Hutan sekunder, kebun kelapa dan tambak yang tidak produktif, belukar rawa mengalami suksesi menjadi hutan primer. Penurunan luas badan air secara terus menerus terjadi karena sedimentasi

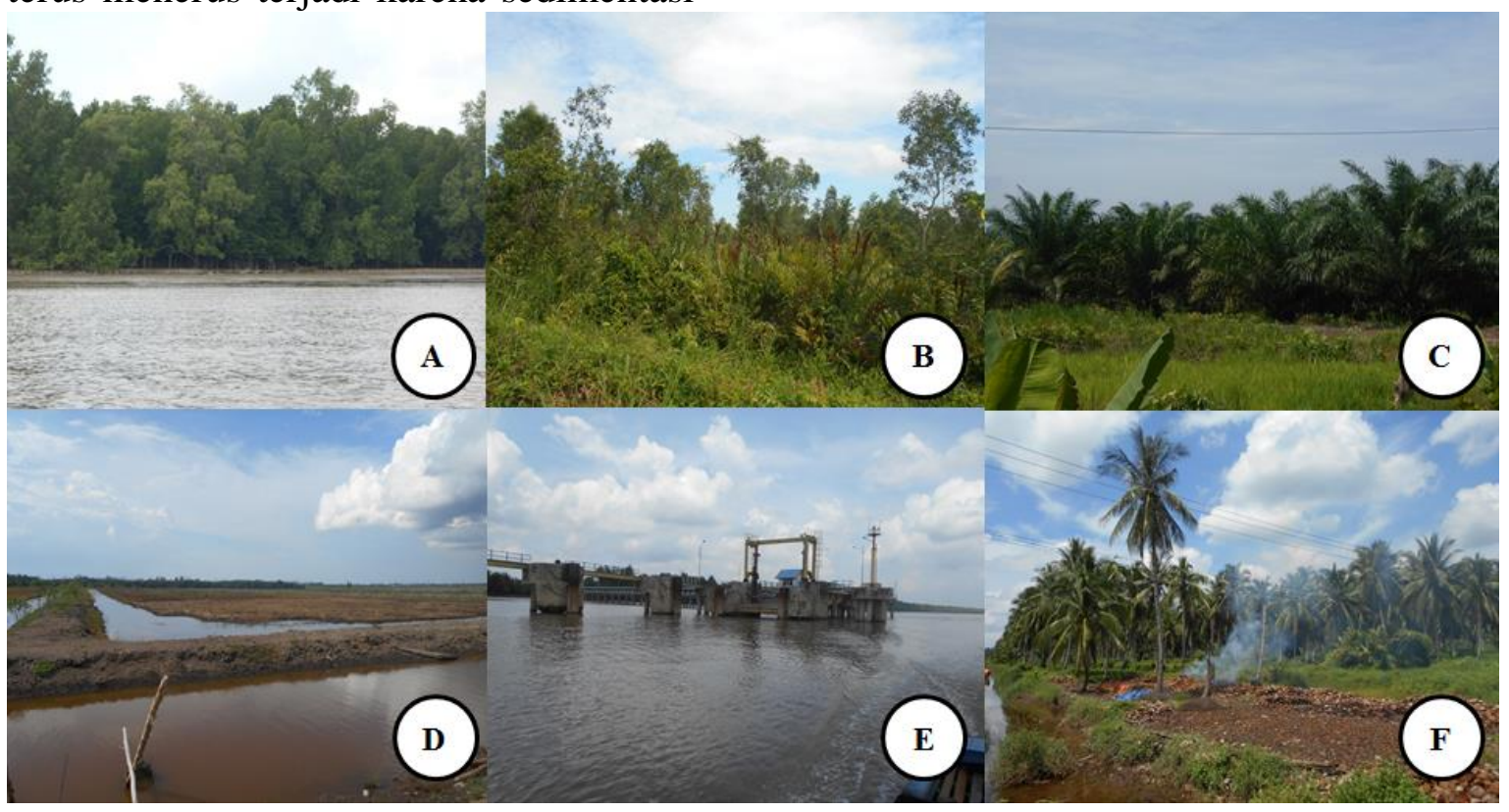

Gambar 4. Keadaan hutan primer (A) dan hutan sekunder (B), serta berbagai bentuk konversi yang terjadi di HLAT (kebun kelapa sawit (C), tambak (D), pelabuhan (E) dan kebun kelapa (F)).

Suksesi yang terjadi pada zona sedimentasi tepi sungai merupakan suksesi primer yang dimulai dari lahan yang semula terbuka (tidak bervegetasi) karena adanya tumpukan endapan lumpur kemudian diinvasi dan dikolonisasi oleh vegetasi mangrove. Seperti halnya yang disampaikan oleh Djohan (2007), bahwa suksesi primer hutan mangrove ditemukan di dataran lumpur yang merupakan hasil dari proses sedimentasi. Sementara itu, suksesi sekunder terjadi pada hutan sekunder yang berkembang menjadi hutan primer. Menurut yang intensif di muara Sungai Banyuasin menyebabkan terbentuknya daratandaratan baru yang mengalami suksesi menjadi hutan primer. Menurut Fromard et al. (2004), kehadiran lumpur yang stabil akibat siklus pasang surut merupakan tahap awal dari proses kolonisasi mangrove di daratan baru yang dimulai dengan dibawanya propagul pohon bakau dalam jumlah besar oleh arus pasang surut. 
produksi perikanan tangkap secara signifikan, sebab hutan mangrove merupakan tempat hidup biota perairan seperti ikan dan udang, baik sebagai tempat hidup, tempat memijah maupun sebagai tempat memelihara anakan. Menurut Eddy et al. (2015) bahwa degradasi hutan mangrove dapat menimbulkan dampak berupa abrasi garis pantai, pendangkalan dan terbentuk daratan baru (akresi), intrusi air laut, penurunan keanekaragaman hayati, penurunan hasil penangkapan ikan dan kepiting.

\section{KESIMPULAN}

Hutan primer yang masih dapat dipertahankan selama periode 1 (19892001) yaitu sebesar $6.978,00$ ha $(55,11 \%)$, sedangkan pada periode 2 (2001-2013) yaitu sebesar 5.671,53 ha $(44,8 \%)$. Penambahan luas hutan primer terjadi karena adanya perubahan dari hutan sekunder, kebun kelapa, belukar rawa, tambak dan badan air menjadi hutan primer. Pengurangan luas hutan primer lebih utama disebabkan karena berubah menjadi hutan sekunder serta konversi menjadi perkebunan kelapa, perkebunan kelapa sawit dan tambak. Restorasi terhadap kawasan HLAT penting dilakukan guna mempertahankan fungsinya sebagai hutan lindung.

\section{DAFTAR PUSTAKA}

Anwar, C. dan Gunawan, H. (2006). Peranan Ekologis dan Sosial Ekonomis Hutan Mangrove dalam Mendukung Pembangunan Wilayah Pesisir. Prosiding Ekspose Hasilhasil Penelitian. Makalah Utama pada Ekspose Hasil-hasil Penelitian: Konservasi dan Rehabilitasi Sumberdaya Hutan (23-34). Padang, 20 September 2006.
Dinas Kehutanan dan Perkebunan Kabupaten Banyuasin. (2010). Laporan Hasil Identifikasi Gangguan Kawasan Hutan Lindung Pantai Air Telang Kabupaten Banyuasin. Dinas Kehutanan dan Perkebunan Kabupaten Banyuasin. Pangkalan Balai.

Djohan, T.S. (2007). Mangrove Succession in Segara Anakan, Cilacap. Berkala Ilmiah Biologi, 6(1), 53-62.

Eddy, S., Iskandar, I., Ridho, M.R. dan Mulyana, A. (2017). Land Cover Changes in the Air Telang Protected Forest, South Sumatra, Indonesia (1989-2013). Biodiversitas, 18(4), 1538-1545.

Eddy, S., Mulyana, A., Ridho, M.R. dan Iskandar, I. (2015). Dampak Aktivitas Antropogenik terhadap Degradasi Hutan Mangrove di Indonesia. Jurnal Lingkungan dan Pembangunan, 1(3), 240-254.

Fromard, F., Vega, C. dan Proisy, C. (2004). Half A Century of Dynamic Coastal Change Affecting Mangrove Shorelines of French Guiana. A Case Study Based on Remote Sensing Data Analyses and Field Surveys. Marine Geology, 208(2004), 265-280.

Giesen, W. Wulffraat, S. Zieren, M. dan Scholten, L. (2007). Mangrove Guidebook for Southeast Asia. Dharmasarn, Co. Ltd. Thailand.

Indriyanto. (2006). Ekologi Hutan. Bumi Aksara. Jakarta: 175 hlm.

Irawan, S. dan Sirait, J. (2017). Perubahan Kerapatan Vegetasi Menggunakan Citra Landsat 8 di 
Kota Batam Berbasis Web. Jurnal Kelautan, 10(2), 174-184.

Kasim, F. (2012). Pendekatan Beberapa Metode dalam Monitoring Perubahan Garis Pantai Menggunakan Dataset Penginderaan Jauh Landsat dan SIG. Jurnal Ilmiah Agropolitan, 5(1), 620-635.

Romiyanto, Barus, B. dan Sudadi, U. (2015). Model Spasial Kerusakan Lahan dan Pencemaran Air akibat Kegiatan Pertambangan Emas Tanpa Izin di Daerah Aliran Sungai Raya, Kalimantan Barat. Jurnal Tanah dan Lingkungan, 17(2), 4753.

Suwargana, N. (2008). Analisis Perubahan Hutan Mangrove Menggunakan Data Penginderaan Jauh di Pantai Bahagia, Muara Gembong, Bekasi. Jurnal Penginderaan Jauh, 5: 64-74.

Utomowati, R. (2017). Dinamika Temporal Tutupan Lahan dan Pengaruhnya terhadap Indeks Fungsi Lindung Daerah Aliran Sungai (DAS) Jlantah Hulu Kabupaten Karanganyar Tahun 2010-2016. Prosiding Seminar Nasional Geografi UMS 2017, (103-117). Surakarta, 22 Mei 2017.

Wibowo, K. dan Handayani, T. (2006). Pelestarian Hutan Mangrove melalui Pendekatan Mina Hutan (Silvofishery). Jurnal Teknik Lingkungan, 7(3), 227-233. 